\title{
PAIXÕES EM CONFLITO NUM DISCURSO JURÍDICO
}

\section{PASSION CONFLICT IN A JURIDICAL DISCOURSE}

\author{
Maria Helena Cruz Pistori* \\ PUC-SP - Pontifícia Universidade Católica de São Paulo
}

\begin{abstract}
RESUMO: O foco deste artigo é a utilização das paixões como argumento persuasivo, tal como preconizado pela Retórica aristotélica. $\mathrm{O}$ avanço contemporâneo dos estudos do discurso nos permite a análise das configurações passionais que ocorrem nos textos, basicamente a indignação e a compaixão; isso permite uma possível previsibilidade das ações dos sujeitos da enunciação. O fundamento teórico do estudo é a semiótica da Escola de Paris, especialmente a semiótica tensiva. Buscamos observar como se constroem os papéis patêmicos dos enunciadores iterativamente ao longo de um processo judicial. Nas considerações finais, tecemos algumas reflexões acerca da moralização das paixões em nossa sociedade.
\end{abstract}

PALAVRAS-CHAVE: Paixões; Persuasão; Semiótica; Discurso Jurídico.

\begin{abstract}
This paper is concerned with the use of the passions as persuasive argument, as advocated by Aristotelian Rhetoric. The progress of studies in contemporary discourse enables us to analyze the configurations of passion occurring in the juridical process chosen, primarily outrage and compassion. The theoretical foundation of the study is the semiotics of the School of Paris, especially the tensive semiotics. We seek to observe the construction of the pathemic roles of enunciators iteratively throughout the process, for this allows a potential predictability of their actions. We add, in concluding remarks, some reflections on the ethical standards of the passions in our society.
\end{abstract}

KEYWORDS: Passion; Persuasion; Semiotics; Juridical Discourse.

Desde Aristóteles, sabemos que, na argumentação, persuadimos por meio das três provas retóricas: o caráter do orador - éthos, as disposições suscitadas nos ouvintes páthos, e o discurso, pelo que ele demonstra ou parece demonstrar - lógos. O avanço contemporâneo dos estudos do discurso nos permite compreender melhor o funcionamento de cada uma delas. Neste trabalho, partimos da antiga retórica para estudar as paixões como argumento em um discurso jurídico, utilizando o arsenal teórico da semiótica greimasiana e pós-greimasiana.

Nosso objeto de análise são as configurações passionais em conflito no processo jurídico relativo ao julgamento dos rapazes de Brasília que assassinaram um índio

\footnotetext{
* Doutora em Letras/USP; pós-doutorado em curso na PUCSP/FAPESP (Proc. 2009/16902-8).
} 
pataxó, cuidando ser um mendigo - Processo $\mathrm{n}^{\circ}$. 17.901-97, do Tribunal do Júri de Brasília. Foi crime de grande repercussão na época e, ainda hoje, eventualmente, vem à tona na mídia, embora tenha ocorrido em 1997. O processo durou quatro anos e sete meses e percorreu as três instâncias judiciais possíveis: na primeira, o juiz singular do Tribunal do Júri acatou a denúncia do crime, mas modificou a tipificação do delito; na segunda, acórdão do Tribunal de Justiça do Distrito Federal - decisão de três desembargadores - manteve a primeira deliberação; na terceira, acórdão do Superior Tribunal de Justiça, também uma decisão de colegiado de quatro ministros, resolveu que a tipificação só poderia ser definida pelo Tribunal do Júri. Assim, o processo voltou para a primeira instância e foi julgado pelo Tribunal Popular, que condenou os réus por homicídio triplamente qualificado - a tese inicial do Ministério Público.

Da sentença não terminativa do feito - a primeira decisão -, retiramos a frase que nos motiva a investigação: "A emoção e indignação causadas pelo trágico resultado não podem afastar a razão" (fl. 5901, grifo nosso). O resultado referido é a morte da vítima. O discurso jurídico se quer racional e razoável, como podemos aí constatar, no entanto uma simples leitura das peças processuais nos mostra a passionalidade nele envolvida que a análise, então, pode desvelar. E este é o objetivo deste trabalho: tratar do entrelaçamento de percursos passionais nesta estrutura conflitual polêmica que é o processo jurídico, apresentando a configuração das paixões presentes e sua relação argumentativa com o universo de acolhida. Compaixão e indignação são os lexemas que as denominam, apesar de o primeiro desses termos não ocorrer uma única vez nos textos. Nesse processo, ambas servem claramente à manipulação do destinatário, são argumentos persuasivos, provocando modulações de intensidade no discurso e contribuindo decisivamente para a modificação de seu percurso.

\section{Paixões, semiótica, retórica}

Nossa fundamentação teórica é a semiótica da escola de Paris, acrescida dos ensinamentos da antiga retórica. De início, lembremos que Aristóteles, na Retórica, destaca especificamente a relação entre o discurso jurídico e as paixões: "nos processos, importam principalmente as boas disposições dos ouvintes, porque os fatos não se revelam através do mesmo prisma, consoante se ama ou se odeia, se está irado ou em inteira calma" (II, 1377b, 20). E continua afirmando que é preciso conhecer a natureza e a qualidade de cada uma delas, sua origem e desenvolvimento no indivíduo para inspirá-las nos ouvintes quando necessário ao discurso.

Ao longo da História, as paixões foram estudadas geralmente como individuais e subjetivas; contudo, conforme já afirmava Aristóteles, elas agem nos discursos sociais, ainda que, muitas vezes, por meio de redes passionais e emocionais sem lexema apropriado em língua natural. Seu aspecto intersubjetivo e social serve ao reconhecimento e qualificação axiológica nas diferentes culturas, lembra-nos Bertrand (2002, p. 303-4).

$\mathrm{O}$ conceito de paixões está intimamente ligado à tensividade. Elas são definidas de acordo com os valores a que visam. São eles que organizam cognitivamente o mundo e polarizam o próprio foco a ele dirigido - valores do absoluto, de caráter exclusivo, ou valores de universo, de caráter participativo-: "será a correlação entre a intensidade afetiva investida no objeto, por um lado, e sua quantidade ou extensão, por outro, que definirão o

\footnotetext{
${ }^{1}$ Seguindo o costume da área jurídica, referimo-nos aqui às "folhas" do processo, e não às suas páginas.
} 
'tipo axiológico' da paixão" (FONTANILLE e ZILBERBERG, 2001, p. 302). E ainda segundo os mesmos autores (2001, p. 49): "Identificamos a exclusão-concentração, regida pela triagem, e a participação-expansão, regida pela mistura, como as duas principais direções capazes de ordenar os sistemas de valores".

No processo judicial, objeto de nossa análise, visamos à definição das configurações passionais enquanto formas estruturais reconhecidas por enunciador/enunciatário, definidoras de papéis patêmicos: ao se manifestarem iterativamente ao longo dos textos, as paixões permitem a previsibilidade de ações e comportamentos, o que lhes assegura o funcionamento argumentativo nos discursos.

\section{A indignação}

Iniciemos as reflexões pela indignação, citada na frase da sentença transcrita acima, que, segundo o enunciado, seguiu-se à emoção causada pelo crime. A emoção é pontual, tônica na dimensão fórica ${ }^{2}$, átona na dimensão modal (FONTANILLE; ZILBERBERG, 2001, p. 300). É exatamente dessa forma que é apresentada na frase, em parte decorrendo daí sua "irrelevância" 3 . Já a indignação é considerada uma paixão desde a Antiguidade e prolonga-se na duratividade. Vejamos o que diz Aristóteles em sua Retórica (1386b, 8-15), atentando, primeiramente, que ele a define em oposição à compaixão:

À compaixão opõe-se particularmente o que se chama a indignação. Com efeito, a pena que se sente pelas desgraças imerecidas de outrem é de algum modo o contrário, embora provenha do mesmo caráter, da pena que se experimenta perante os êxitos imerecidos. Estes dois sentimentos provêm de um natural honesto. Em face das desgraças imerecidas, devemos compartilhar a dor daqueles que as sofrem, compadecer-nos delas e indignarmo-nos perante os êxitos injustificados. É injusto aquilo de que beneficiamos sem que o tenhamos merecido; por isso atribuímos aos deuses a indignação que pune.

Comparemos com a definição do Dicionário Houaiss (2002): “1. sentimento de cólera ou de desprezo experimentado diante de indignidade, injustiça, afronta; repulsa, revolta. 2. derivação: por extensão de sentido, ira intensa; ódio, raiva".

Nas duas definições, os pressupostos para que ocorra a indignação são os mesmos: (i) é necessária uma situação disfórica, especificamente de "injustiça" (de disjunção com o Direito). Em Aristóteles, tanto a compaixão quanto a indignação relacionam-se ao merecimento, à "injustiça" (desgraça imerecida suscita compaixão; êxito imerecido, "injustificado", indignação); no Dicionário, a indignação é experimentada diante de "indignidade, injustiça, afronta"; (ii) é necessário que o sujeito que se indigna se reconheça como "honesto, digno" - queira estar conjunto com o Direito. Houaiss define a dignidade como "qualidade moral que infunde respeito; consciência do próprio valor; honra, autoridade, nobreza". Logo é a injustiça da situação que provoca a indignação de um homem digno,

\footnotetext{
${ }^{2} \mathrm{Na}$ semiótica greimasiana, a foria se constitui na categoria que expressa o modo como o ser vivo, inscrito em um contexto, "se sente e reage a seu meio": positivamente - por meio da euforia -, ou negativamente - por meio da disforia (cf. BARROS, 2002, p.24).

3 "Irrelevância" se tomarmos como critério a frase transcrita anteriormente, da primeira decisão, que destaca a necessidade de racionalidade nas decisões no Direito: “A emoção e indignação causadas pelo trágico resultado não podem afastar a razão" (fl.590, grifo nosso).
} 
aquele que "tem ou revela dignidade ou elevação de caráter; honestidade, honradez" (HOUAISS).

Em relação ao objeto de valor, a indignação se define como um poder/querer não estar disjunto do Direito. Se o poder/querer estar conjunto com o Direito são valores modais pressupostos e a garantia do Estado Democrático do Direito, valores universais, a indignação surge quando o antissujeito não respeita esses valores, total ou parcialmente, valorando uma situação de forma diferente.

O sujeito que defende os valores universais no processo - o Direito para todos, é o Ministério Público. Na própria Denúncia, ao descrever o crime, demonstra a ligação do delito com a "barbárie", pois "GALDINO era índio e não podia imaginar que fosse atacado por homens brancos - tidos como civilizados -, enquanto dormia, completamente desprotegido, sobre um banco de avenida principal da Capital da República” (fl.04). Na busca da sensibilização do outro, também nas ALEGAÇÕES FINAIS, anterior à sentença que nos traz o mote, retoma: "Não se brinca com tamanha dor nem de um animal, quanto mais de um desprotegido ser humano" (fl.516). A defesa, na busca de uma justificação ou atenuação da tipificação penal e de uma consequente redução penal, também está conjunta com o Direito, mas Direito como valor exclusivo, de poucos - o dos réus, garantido constitucionalmente. É, então, o antissujeito.

Compreendamos melhor os efeitos passionais nesse processo, refletindo acerca de outro aspecto da definição de Houaiss do qual ainda não tratamos: sentimento de cólera ou desprezo ${ }^{4}$. A palavra "ou" tem valor exclusivo; no processo, encontramos a indignação mais próxima da cólera que do desprezo. Segundo o mesmo Dicionário, a "cólera é sentimento de violenta oposição contra o que revolta, escandaliza, molesta ou prejudica; intensa raiva facilmente provocável; ira". Para tratarmos da cólera, porém, não há como fugir dos estudos de Greimas (1983, p. 225-246) e de Fontanille (2005, p. 61-79).

Indignação e cólera são paixões aparentadas; mas, de início, diferem no pressuposto: só a primeira é sentimento proveniente de um homem honesto, justo, que pode e quer não ser disjunto com o Direito. Comparemo-la, ainda, com a sequência canônica, apresentada por Greimas e ampliada por Fontanille, que vai funcionar para definirmos a indignação, ainda que apenas até certa etapa - aquela em que o sujeito passa do poder/querer ser ao fazer. Segundo Fontanille, a cólera resulta da sucessão de:

$$
\text { CONFIANÇA } \rightarrow \text { ESPERA } \rightarrow \text { FRUSTRAÇÃO } \rightarrow \text { DESCONTENTAMENTO } \rightarrow \text { AGRESSIVIDADE } \rightarrow \text { EXPLOSÃO }
$$

A confiança e a espera (em Greimas, a espera fiduciária) são exigidas pelo próprio sistema jurídico, instituição responsável, em primeiro lugar, pelo dever dizer o Direito. O Processo Penal regra o procedimento, ditando os prazos, as possibilidades de intervenção de cada parte; deve, assim, proporcionar formalmente "segurança jurídica" à sociedade, crença num devir que deve ser reconhecido como legal. Exemplos dessa espera fiduciária da justiça encontramos em textos da Acusação e das Defesas, ora por meio de um futuro deontológico, aquilo que deve ser (cf. FIORIN, 2001, p. 154), ora pela utilização do presente do subjuntivo indicando a posterioridade.

\footnotetext{
${ }^{4} \mathrm{O}$ desprezo é definido, pelo mesmo Dicionário, como "1. falta de estima, apreço ou consideração; desdém; 2. sentimento pelo qual o espírito se transporta acima da cobiça, do medo etc.; desprendimento; 3. sentimento de repulsa”.
} 
... deverá este crime ser objeto de deliberação do Tribunal do Júri... (fl. 5167 , grifos nossos)

Roga-se, ainda, a este MM. Juízo Privativo do Tribunal do júri da Circunscrição Judiciária de Brasília... que desclassifique o crime de homicídio doloso, triplamente qualificado... na denúncia, ao réu, para a exata capitulação que decorra da íntima convicção desta digna Magistrada, cujo amplo conhecimento dos autos lhe permitirá dizer, com segurança jurídica e certeza moral, não ter agido o acusado com o animus necandi... (fl.554, grifos em itálico nossos, grifos em negrito do autor)

Neste processo, a defesa acolheu com satisfação a sentença de desqualificação do crime, propondo inclusive um recurso a fim de que fosse logo publicada "para conhecimento da comunidade jurídica, pois o caso de que se cuida é singular. Tem alcançado os mais amplos segmentos da sociedade, bem assim divulgação nunca vista em todos os meios de comunicação social" (fl.614). Ao acatar a tese defensória, porém, a sentença frustrou a espera fiduciária não apenas do Ministério Público, mas também da própria sociedade por ele representada.

O sentimento de frustração é percebido como privação do Direito e, ainda, como quebra de confiança numa promessa anterior (de justiça), como se houvesse ruptura (unilateral) do contrato fiduciário. Essa sensação envolve o próprio corpo, caracteriza a frustração e gera a indignação. "A afetividade reivindica o corpo de onde emana e que ela modifica" (FONTANILLE, 2003, p. 188). Antes, porém, de verificar como essa frustração e o descontentamento se manifestam no recurso do Ministério Público, atentemos a seu título, previsto no Direito Processual Penal, formulaico, no entanto, passional: RAZÕES DE IRRESIGNAÇÃO.

A irresignação se segue ao descontentamento e à indignação, levando à ação, ao dever fazer: é "falta de resignação" (HOUAISS) que, por sua vez, é "submissão à vontade de alguém ou destino". No processo penal, nessa fase, a irresignação é prevista, pois só não cabem mais recursos da decisão transitada em julgado. A irresignação do MP significa que hierarquiza seu querer/poder estar conjunto com o Direito como mais intenso do que o querer/poder da instância decisória. Seguindo o procedimento legal, manifesta-se não submisso à vontade expressa na decisão legal. Assim, ao invés de acatá-la como terminativa, propõe compreendê-la de modo incoativo, como pretexto a novo exame dos fatos, agora numa instância superior. A sequência passional da indignação que propomos, observados os dados processuais, é a seguinte:

\section{CONFIANÇA $\rightarrow$ ESPERA $\rightarrow$ FRUSTRAÇÃO $\rightarrow$ DESCONTENTAMENTO/INDIGNAÇÃO $\rightarrow$ IRRESIGNAÇÃO}

Nela, o descontentamento e a indignação concomitantes levam à irresignação que, por sua vez, gera a ação. Vejamos exemplos nas RAZÕES DE IRRESIGNAÇÃO, começando por alguns dos muitos itens que bradam enfaticamente seu descontentamento com a decisão por meio dos negritos e/ou grifos (no original):

Não foi um ato impulsivo, de momento. (fl. 623, grifo nosso)

A fuga precedeu o socorro tardio. (fl. 626) 
Dolo eventual nunca foi "intencional". Se fosse, para que a diferenciação? Se o "assumir o risco" significa "querer", por que o dolo eventual? Bastaria o dolo direto. Se homens de dezoito, dezenove e vinte anos, sem qualquer debilidade mental, com educação "esmerada", podem jogar dois litros de álcool diretamente sobre o corpo de um mendigo, atear fogo, tudo de forma demorada, planejada, estudada, e isto significa que "não assumiram o risco de matar", o que é assumir o risco de matar?! (fl.629, grifo nosso)

Os recursos gráficos nos indicam a forma sensível como a frustração, o descontentamento e a indignação se expressam no enunciado até por meio da gradação na relevância do que é dito, o que recupera a modulação entonacional (indignada!) da oralidade. Não só isso, também a proliferação de exclamações e interrogações no texto e a aceleração das frases curtas forçam uma respiração rápida e indignada ao leitor.

Os papéis patêmicos dos enunciadores se constroem ao longo do processo (cf. FONTANILLE, 2003, p. 187) iterativamente e são fatores de previsibilidade de comportamento das partes, principalmente por sua estereotipia (cf. GREIMAS e FONTANILLE, 1993, p. 83). O papel patêmico do MP, que já se delineava desde o início, a partir desta peça, passa a se construir com maior nitidez e mantém-se ao longo do processo: o sujeito indignado com o crime, indignado com a decisão, indignado com a injustiça na distribuição dos valores universais. Um papel de maior intensidade, mas que se coaduna com aquele do sujeito compassivo, modalizado pelo querer/poder estar conjunto com o Direito como valor do universo, de todos.

A intensidade da indignação é máxima nesta peça, mas acompanha a extensão toda do processo, decorre num ritmo lento, na duratividade; do ponto de vista da dimensão modal, é tônica. O ritmo lento corresponde ainda à intensidade da paixão suscitada pela parte contrária, pois há necessidade de responder a ela, renovando constantemente sua posição, a cada nova invectiva: a reiteração dos argumentos visa ao não apaziguamento da indignação social. Ela também deve ser utilizada persuasivamente pela Acusação e não pode diminuir de intensidade...

\section{A compaixão}

A paixão contrária à indignação é a compaixão. Sobre ela, fala o Estagirita, conforme tradução de A. Pinto de Carvalho (II, 1385b, 13):

Admitamos ser a compaixão uma espécie de pena causada por um mal aparente capaz de nos aniquilar ou afligir, que fere o homem que não merece ser ferido por ele, quando presumimos que também nós podemos sofrer, ou algum dos nossos, e principalmente quando nos ameaça de perto. Evidentemente é mister que o homem que haja de sentir compaixão pense que ele próprio, ou algum dos seus, é suscetível de sofrer de um mal idêntico ao que indicamos em nossa definição, ou de mal análogo, ou parecido.

Comparemos com a definição de Houaiss (2002): "Sentimento piedoso de simpatia para com a tragédia pessoal de outrem, acompanhado do desejo de minorá-la; participação espiritual na infelicidade alheia que suscita um impulso altruísta de ternura para com o 
sofredor". Na tradução francesa da Retórica ${ }^{5}$, compaixão aparece como pitié, o que mais uma vez nos remete aos estudos de Fontanille (2005, pp. 240-265), agora sobre a piedade. A definição de Houaiss também lembra a piedade - "sentimento piedoso de simpatia", assim como a própria "simpatia" 6 , etimologicamente equivalente à compaixão.

Nas duas definições, os pressupostos para que se sinta a compaixão são os mesmos, conforme levantados por Fontanille $\left(2005\right.$, p. 241) ${ }^{7}$ : (i) é necessário que o outro esteja numa situação disfórica (seja acometido de "um mal aparente capaz de nos aniquilar ou afligir"; de uma "tragédia pessoal"); (ii) é necessário que o outro seja reconhecido como um semelhante - a simpatia (em Houaiss), ou seja, que haja ao menos um traço compartilhado que identifique o outro com nós mesmos. É um sentimento que se define em relação ao outro como "impulso altruísta", de "ternura", que o mesmo Dicionário define como "afeto brando, sem transportes emotivos".

Fontanille (2005, pp. 264-5) afirma que a compaixão pode ser particularmente eficaz como manipuladora. Vejamos o esquema básico que propõe para defini-la:

\section{SENSIBILIZAÇÃO PARTICIPANTE $\rightarrow$ CLASSIFICAÇÃO $\rightarrow$ EQUALIZAÇÃO $\rightarrow$ IDENTIFICAÇÃO}

A partir da identificação passional é que se verifica sob que semelhança se funda o sentimento de compaixão visado pelo enunciador. Assim, são pressupostas as etapas anteriores: a equalização, por meio da qual se eleva ou se inferioriza uma das partes e graças à qual, por alguma manifestação figurativa, ocorre a manipulação passional enunciador/enunciatário ${ }^{8}$ (fase do dom para o enunciatário e do prazer para o enunciador); a classificação e reconhecimento do semelhante, sobre a qual incide a perspectiva temporal em que esse reconhecimento se dá: a compaixão ocorre em relação às origens comuns, à situação aflitiva ou ao devenir, e a primeira etapa é da sensibilização participante, que abala o enunciatário.

Vejamos, sob quais bases de semelhança, se a compaixão é suscitada pelas partes, tanto pela Acusação, em relação à vítima, quanto pelas Defesas, em relação ao sofrimento dos réus, que "não tinham a intenção de assassinar a vítima" (apenas queriam fazer uma "brincadeira"). E, ainda, se o enunciador a expressa como o querer/poder estar conjunto com o Direito - independente da situação, isto é, como um sentimento potencial -, ou como o querer/poder estar conjunto com o outro em sua tragédia pessoal presente, projetando antecipadamente suas necessidades e desejos.

Uma reação baseada na identificação afetiva com o outro a partir de, ao menos, um traço comum, objetivável é buscada, de início, pelo Ministério Público já na Denúncia. Aí se destaca o traço de humanidade da vítima, que "dorme, desprotegida" - o indígena -, como relevante na identificação com o sofrimento de sua família, de sua tribo. Ainda vemos, no processo, a compaixão utilizada pelo Ministério Público com base numa semelhança genérica e politicamente reconhecida de forma bastante acentuada. É o princípio da igualdade de todos perante a lei que deve nos levar à compaixão em relação a qualquer ser humano que não tenha

\footnotetext{
${ }^{5}$ Texto estabelecido e traduzido por Médéric Dufour, Ed. Les Belles Lettres.

${ }^{6}$ Simpatia, no entanto, alterou seu sentido. Cf. Houaiss, 2002.

${ }^{7}$ Apesar de utilizarmos esse estudo, extrairemos dele apenas o que corresponde à compassion, equivalente ao português compaixão. A pitié pode corresponder também à pena, ou à piedade-desprezo, que não pressupõe o ser semelhante, mas apenas a situação disfórica. É a versão positiva que aproveitamos aqui.

${ }^{8}$ No estudo, Fontanille trata de obrigador e obrigatário. Considerando que, no processo, as paixões são suscitadas pelos sujeitos da enunciação, enunciador/enunciatário, restringimo-nos a essa terminologia.
} 
seu direito à vida respeitado. É um sentimento potencial, aberto a todo tipo de possibilidades, não terminado, durativo. Nada pode justificar, pois, o crime: "Nenhum deles era alienado, não estavam, em princípio, nem embriagados e nem drogados e, obviamente, tinham plena consciência dos efeitos do gesto ignóbil. Não se brinca com tamanha dor nem de um animal, quanto mais de um desprotegido ser humano" (fl.516).

Do outro lado, as defesas procuram despertar a compaixão do enunciatário a partir de outro ponto comum, também afetivo, em relação ao enunciador. Particularmente a defesa de MRA, o primeiro dos réus nominado, visa, num primeiro momento, ao compartilhamento do sentimento de paternidade/maternidade, independente de classe social. Isso pode ser verificado por um observador externo que reconhece, nos vários enunciados do enunciador/defensor/padrasto, a demonstração de um sofrimento particular em relação ao crime praticado pelo enteado: “... [é] dependente do ora impetrante, com residência fixa... e escritório estabelecido no endereço constante ao pé da página..." (fl.274. Sem negrito no original). Essa compaixão se dirige à situação disfórica atual e é despertada pelo querer estar junto de outro semelhante, também pai/mãe, participando de seu sofrimento.

Não só isso, as defesas também suscitam o querer estar junto de outro semelhante da mesma classe social: o enunciador cria o enunciatário que partilha os mesmos privilégios do enunciador adepto, como ele, de uma ética da convicção (cf. FONTANILLE \& ZILBERBERG, 2001, pp. 54-55), que separa o fato de suas consequências e, portanto, vê o crime cometido como um fato isolado na vida dos réus. Assim, a defesa de ANCV também apela, em primeiro lugar, ao sofrimento do réu perante a repercussão do crime praticado: “A tragédia que se abateu sobre a vítima não está muito além da que explodiu sobre a cabeça dos ora acusados" (fl.561). A defesa de MRA, contudo, é mais incisiva no despertar a compaixão baseada no privilégio pelas várias vezes, ao longo do processo, em que enumera as características de família "bem estruturada", com educação "esmerada e sólida", de instrução intelectual em "colégios privados", com "domicílio em área nobre da Capital, do trabalho em renomado escritório de advocacia".

Por outro lado, ao verificar que seus argumentos não surtiram o efeito desejado, isto é, que não motivaram a compaixão do adversário, "seu igual" tanto em termos de paternidade-maternidade, camada social privilegiada e ainda de pertencimento ao meio forense, essa defesa recorre ao ressentimento: "mágoa que se guarda de uma ofensa ou de um mal que se recebeu" (HOUAISS, 2002). Isso ocorre particularmente nas CONTRARRAZÕES que respondem às RAZÕES DE IRRESIGNAÇÃO do MP, em que passa a agredir e desqualificar o adversário, a mídia e os políticos. O ressentimento é também aparentado com a indignação e a cólera. Se observarmos as fases que levam à cólera: confiança / espera / frustração / descontentamento / agressividade / explosão, o ressentimento situa-se no momento posterior à frustração, do mesmo modo que a indignação. Inicialmente, pressupõe um antissujeito, que frustra uma espera fiduciária. Assim, da parte dessa defesa, havia uma esperança de compaixão em relação ao réu, produto da manipulação expressa nas outras peças defensórias. No entanto, embora na sentença tenha havido a sensibilização, a acusação não só rejeitou fortemente a compaixão, como manteve, e até mesmo avolumou sua indignação nas RAZÕES DE IRRESIGNAÇÃO.

Destinado a durar indefinidamente, o ressentimento guarda a memória de uma cólera não saciada (cf. FONTANILLE, 2005, pp. 69-74). O saber não ter podido modificar o estado de espírito do outro leva esta defesa ao descontentamento e à agressividade, primeiro, em relação ao adversário, como em: 
Depois de insistir na tese da diversão 'até às três horas da madrugada', diz a Promotoria, cheia de ódio e ressentimento, que os cinco rapazes "trocaram de carros numa surpreendente sequencia de vezes" carregando as tintas da cizânia sobre um dos acusados: 'Só MAX, naquela noite fatídica, usou diversos carros de luxo, alguns importados, muito acima dos padrões dos carros brasileiros comuns'.

Percebe-se, nesse ponto, um laivo de inveja, uma ponta de inconformismo da acusadora oficial, como se fosse pecado alguém, depois de vários anos de trabalho sério e anônimo, possuir mais de um carro importado ou não. Parece não ser, evidentemente, da alçada da 'Fiscal da Lei' imiscuir-se em área não afeta à sua competência legal (fl. 758).

Não se faz uma análise fria e desapaixonada da ação criminosa em pauta, mas um estudo fantasioso, fúnebre e tendencioso dos lamentáveis acontecimentos (fl. 761).

Em seguida, em relação à mídia:

Por aí se vê [referência à fraude eletrônica que afirma ter ocorrido na TV Globo], eg. Tribunal, quanto é tendenciosa, artificial, fraudulenta e desonesta a posição assumida pela mídia, em relação aos fatos que a ela interessa explorar mercantiliscamente. Não há qualquer compromisso com a verdade, senão com os interesses escusos de tais órgãos noticiosos que querem cada vez mais "ibope" (fl. 774).

E, finalmente, em relação aos políticos:

Por que o Presidente falastrão, ao levantar essa cortina de fumaça, não exige punição rigorosa para os áulicos que o rodeiam, com a compra de votos para a aprovação da emenda de que se tornou beneficiário direto, exigindo reprimenda apenas para os réus, bodes expiatórios que, em boa hora para ele, se tornaram alvo predileto da execração pública (fl. 775)

Finalmente, a sincronização afetiva também é buscada, por vezes, pelo sujeito da enunciação, tanto no caso do Ministério Público, como das instâncias decisórias. Ela se realiza por meio da opinião pública, grande responsável por uma estratégia de persuasão social, que eventualmente aparece no discurso como se fosse o outro nome dado ao enunciatário (LANDOWSKI, 1992, pp. 19-43). Em crimes dessa natureza e repercussão, a manipulação pelo contágio sincroniza intersomaticamente a reação popular ${ }^{9}$. O contágio é responsável pela difusão dos afetos e leva a opinião pública ${ }^{10}$ a exercer o papel de Destinador, servindo de adjuvante-manipuladora no processo, ao lado do Estado, que seria o Metadestinador. Isso acontece graças também à força (até certo ponto, sensacionalista) da

\footnotetext{
${ }^{9}$ Consideramos que aqui se aplica analogamente a concepção de uso interativo do contágio tal como Landowski (2004) aponta no estudo sobre a reação do povo ante a morte da princesa Diana.

10 A opinião pública serve às estratégias de persuasão social e está à disposição de perspectivas várias, por vezes até opostas. Sujeito reflexivo, a exercer sua ação sobre a própria sociedade, tem dupla vocação actancial: manipulador ou manipulada. (cf. LANDOWSKI, 1992, p.19-43).
} 
mídia e dos políticos. Transcrevemos trecho de decisão que decretou a prisão preventiva dos réus, baseada na garantia da ordem pública e no clamor social:

... o periculum in mora revela-se pelos requisitos da garantia da ordem pública, por conveniência da instrução criminal ou para assegurar a aplicação da lei penal.

Volto aos autos e constato que, a par da primariedade e dos bons antecedentes dos réus, a ordem pública restou abalada face à gravidade e violência do crime que vitimou Galdino Jesus dos Santos. A conduta dos acusados causou sensível clamor na população local e, inclusive, repercussão extremamente negativa fora do País (f1.267, grifo em itálico nosso)

Tal utilização estratégica da opinião pública é denunciada pela defesa em vários pontos, inclusive buscando a diferença entre garantia de ordem pública e clamor público, mais particularmente nas ALEGAÇÕES FINAIS de MRA, fl.542.

Como podemos perceber, em primeiro lugar, a compaixão suscitada pela acusação e pela defesa não é a mesma, apesar de responderem a um mesmo lexema. Muda, para cada uma, o valor do objeto - o Direito -, ora visto como valor universal, ora como valor exclusivo. E isso faz toda a diferença. Em segundo lugar, há a questão das modalidades. $\mathrm{O}$ poder é modalidade exógena, e o poder ser conjunto com o direito como valor universal é garantido pelo Estado Democrático, é possibilidade de todos; mais do que isso, é dever cívico. Já o querer é modalidade endógena; se o querer ser conjunto com UM direito direito como valor absoluto - é uma virtualidade, não é, necessariamente, positivamente sancionado em nossa sociedade. Mas, sobre a moralização das paixões, trataremos mais adiante.

A manipulação passional enunciador/enunciatário em relação aos réus "sobre cujas cabeças explodiu uma tragédia" é claramente bem sucedida na sentença de desqualificação, que, por isso mesmo, intensifica a indignação do MP ante o delito e a decisão. A partir das semelhanças - em termos de valores familiares ou de classe social, um contrato de confiança se instaura e permite a ocorrência da desclassificação do delito -, ocorre o dom ${ }^{11}$ : a sentença é vista exatamente assim pela defesa de MRA, que até interpõe um recurso (negado) a fim de que seja publicada para conhecimento de todos. No entanto não será um contrato que permanecerá inalterado ao longo do processo, pois, ao se modificar a tipificação do crime, ele parece se romper, ao menos parcialmente. Na sentença final, porém, podemos verificar sua permanência latente.

O esquema afetivo (FONTANILLE \& ZILBERBERG, 2001, pp. 282-285) da paixão se revela pela relação entre as valências do tempo e da intensidade com as valências durativas e modais (do querer e do poder). Se, do ponto de vista da foria, a compaixão decorre num ritmo lento, mas, na duratividade, contínuo, do ponto de vista da dimensão modal, a compaixão é tônica, um intenso querer/poder estar junto com o Direito (de todos valor universal -, ou de alguns - valor do privilégio). Porém quanto mais rápido o tempo da paixão, menos tônica a modalidade. Assim, se a compaixão se define, para a Defesa, pelo

\footnotetext{
${ }^{11}$ Fontanille trata do regime do dom e da dívida entre um "obrigador" e um "obrigatário", unidos por um contrato baseado na compaixão, especialmente propício aos efeitos passionais. Instaurado na duratividade, acontece com aquela compaixão que se preocupa não apenas com a situação disfórica atual do semelhante, como também com o devenir (cf. FONTANILLE, 2005, pp. 261-265).
} 
apego aos direitos do privilégio, quanto maior o apego a esses direitos, mais lentamente se estende o apelo à compaixão ao longo do processo, de forma reiterada, na multiplicação de peças permitidas pelo procedimento processual e repetição de argumentos. É interessante notar que, neste processo, o papel patêmico da Defesa corresponde muito claramente à definição aristotélica - individualista (não à de Rousseau - genérica, política) -, particularmente quando o Filósofo se refere àquilo que "nós podemos sofrer, ou algum dos nossos", ou quando afirma que o "homem que haja de sentir compaixão pense que ele próprio, ou algum dos seus, é suscetível de sofrer de um mal idêntico..." O efeito de sentido buscado é o apaziguamento da indignação: se o processo se estender mais no tempo, a possibilidade de conseguir resultados positivos - pena mais leve para os réus - pode ser maior. A indignação social suscitada pelo crime e utilizada persuasivamente pela Acusação pode diminuir de intensidade ${ }^{12}$.

A direção afetiva, tanto das peças produzidas pelo Ministério Público quanto daquelas produzidas pela Defesa, mantém-se ao longo do processo e define um estilo afetivo para cada parte. Verificamos que esta fixação na compaixão, ligada a valores do exclusivo, define, de maneira destacada, o estilo afetivo da defesa e, mais propriamente, da defesa de MRA, marcando uma atitude energicamente ativa, concentrada em valores próprios: há a subordinação de seu fazer a seu ser, isto é, sua ação defensiva é fiel àquilo que crê ser seu papel pessoal e social (cf. Fontanille \& Zilberberg, 2001, p. 292).

A concentração de um valor impõe necessariamente o enfraquecimento do termo correlato. Assim, compaixão e indignação definidas culturalmente em nossa sociedade têm seu papel regulado pelo Destinador coletivo de forte cunho social: no processo, aparecem como definidoras de classe social, de posições sociais mais ou menos privilegiadas. A defesa ordena seus valores por meio da triagem, a partir da exclusão-concentração; já o Ministério Público vai em direção oposta, a partir da participação-expansão de valores regida pela mistura, coerente com o Estado Democrático de Direito.

\section{A moralização das paixões no processo}

A relação entre as paixões presentes no processo e os valores a elas ligados apontam para uma ética que indica o justo e o adequado diante da situação concreta do crime. A democracia, ou, mais especificamente, o Estado Democrático de Direito em que vivemos, não prevê as paixões, mas garante os direitos que constituem objetos de valor no processo. A própria Constituição Federal dá suporte e referenda essa ética, conforme observamos no art. 5. , que aborda os direitos em confronto: direito à vida, à liberdade, à igualdade e à ampla defesa:

Todos são iguais perante a lei, sem distinção de qualquer natureza, garantindo-se aos brasileiros e aos estrangeiros residentes no País a inviolabilidade do direito à vida, à liberdade, à igualdade, à segurança e à propriedade, nos termos seguintes:

$[\ldots]$

LV - aos litigantes, em processo judicial ou administrativo, e aos acusados em geral são assegurados o contraditório e ampla defesa, com os meios e recursos a ela inerentes;

\footnotetext{
12 Tal como acontece com a cólera fragmentada no exemplo de Sêneca utilizado por Fontanille \& Zilberberg (2001, p. 305-306).
} 
De forma ampla, poderíamos afirmar que esses direitos se inserem na axiologia constante da taxionomia cultural brasileira, uma grade cultural que revela modos de sentir que levam a modos de agir. Completando: como parte da cultura ocidental, nesses aspectos não nos diferenciamos particularmente da sociedade grega de Aristóteles ou da francesa de Greimas e Fontanille, razão pela qual as definições por eles apresentadas adaptam-se aos propósitos deste trabalho, auxiliando-nos a compreender os sentidos passionais discursiva e processualmente produzidos.

Presente na acusação e na defesa de formas diferentes, na medida em que o objeto de valor a que se apegam é apreendido com maior ou menor extensão, a compaixão pode se mostrar mais ou menos socialmente justa. Assim, em relação a ela, a axiologia cultural brasileira assenta-se na correlação conversa: quanto mais poder/querer estar junto com o direito (de todos), mais justa a compaixão - compaixão política, todos iguais perante a lei. Já a indignação, dirigindo-se a posições tomadas pelo antissujeito - a defesa (e antes, os próprios agentes do crime) -, baseia-se na correlação inversa: quanto menos o antissujeito quer e pode estar junto do direito de todos, mais justa a indignação.

Os deveres cívicos expressam-se no princípio da legalidade: "Ninguém será obrigado a fazer ou deixar de fazer alguma coisa senão em virtude de lei" (CF., art. 5. ${ }^{\circ}$, inc. II). Daí decorrer, como nos mostra o processo e já afirmavam Greimas e Fontanille (1993, p. 83), que "os comportamentos [sejam] socialmente normatizados, codificados como papéis temáticos na competência dos sujeitos, permanecendo no âmbito de um contrato coletivo e de uma competência moral ordinária" (Greimas \& Fontanille, 1993, p. 83). Por isso, as paixões expressas pela Acusação e pelas Defesas são moralmente aceitas quando condizentes com os deveres cívicos e com os direitos fundamentais expressos na Constituição Federal, particularmente em seus art. $1 .^{\circ}$ e art. $3 .^{\circ}$ :

Art. $1^{\circ}$ A República Federativa do Brasil, formada pela união indissolúvel dos Estados e Municípios e do Distrito Federal, constitui-se em Estado Democrático de Direito e tem como fundamentos:

$[\ldots]$

II - a cidadania;

III - a dignidade da pessoa humana;

[...]

Art. 3. ${ }^{\circ}$ : Constituem objetivos fundamentais da República Federativa do Brasil:

I - construir uma sociedade livre, justa e solidária.

\section{Referências bibliográficas}

ARISTÓTELES. Arte Retórica. Trad. Antônio Pinto de Carvalho. Rio de Janeiro: Ediouro s/d. Rhétorique. Livre I e II. Texte établi et traduit par Méderic Dufour. $3^{\text {ème }}$ ed. triage. Paris: Les Belles Lettres, 1967.

BARROS, Diana L. P. Teoria do discurso. Fundamentos semióticos. 3. ed. São Paulo: Humanitas/FFLCH/USP, 2002, 172 p.

BERTRAND, Denis. Sémiotique littéraire. In HENAULT, A. Questions de sémiotique. Paris, Presses Universitaires de France, 2002, p. 283-319. 
CONSTITUIÇÃO DA REPÚBLICA FEDERATIVA DO BRASIL DE 1988. http://www.planalto.gov.br/ccivil_03/constituicao/constitui\%C3\%A7ao.htm Acesso em 15/12/2009.

DICIONÁRIO ELETRÔNICO HOUAISS DA LÍNGUA PORTUGUESA. Versão 1.0.5. 2002.

FIORIN, José Luiz. As astúcias da enunciação: as categorias de pessoa, espaço e tempo. 2. ed. São Paulo: Ática, 2001, 318 p.

FONTANILLE, Jacques \& ZILBERBERG, Claude. Tensão e significação. Trad.Ivã Carlos Lopes, Luiz Tatit e Waldir Beividas. São Paulo: Discurso Editorial: Humanitas/FFLCH/USP, 2001, 331 p.

FONTANILlE, Jacques. Sémiotique des passions. In Henault, A. Questions de sémiotique. Paris, Presses Universitaires de France, 2002, p.601-637.

Sémiotique du discours. Limoges: PULIM, 2003, 303p.

Colère. In: RALLO DITCHE, E. ; FONTANILLE, J. ; LOMBARDO, P.

Dictionnaire de passions littéraires. Paris, Belin, 2005, p. 61-79

.Pitié. In: RALLO DITCHE, E. ; FONTANILLE, J. ; LOMBARDO, P. Dictionnaire

de passions littéraires. Paris, Belin, 2005, p. 240-265.

GREIMAS, A. J. Du sens II. Paris: Seuil, 1983.

GREIMAS, A. J. \& FonTANILle, J. Semiótica das paixões. São Paulo: Ática, 1993.

LANDOWSKI, E. A sociedade refletida. Trad.Eduardo Brandão. São Paulo: Educ/Pontes, 1992.

. Passion sans nom. Paris: Presses Universitaires de France, 2004. 